\title{
Amphetamine-evoked gene expression in striatopallidal neurons: regulation by corticostriatal afferents and the ERK/MAPK signaling cascade
}

\author{
Susan M. Ferguson* and Terry E. Robinson*^† \\ *Neuroscience Program and $\dagger$ Department of Psychology, University of Michigan, Ann Arbor, Michigan, USA
}

\begin{abstract}
The environmental context in which psychostimulant drugs are experienced influences their ability to induce immediate early genes (IEGs) in the striatum. When given in the home cage amphetamine induces IEGs predominately in striatonigral neurons, but when given in a novel test environment amphetamine also induces IEGs in striatopallidal neurons. The source of the striatopetal projections that regulate the ability of amphetamine to differentially engage these two striatofugal circuits has never been described. We report that transection of corticostriatal afferents selectively blocks, whereas enhancement of cortical activity with an ampakine selectively augments, the number of amphetamine-evoked c-fos-positive striatopallidal (but not striatonigral) neurons. In
\end{abstract}

addition, blockade of the extracellular signal-regulated kinase $(\mathrm{ERK}) /$ mitogen-activated protein kinase (MAPK) signaling cascade preferentially inhibits the number of amphetamineevoked c-fos-positive striatopallidal neurons. These results suggest that glutamate released from corticostriatal afferents modulates the ability of amphetamine to engage striatopallidal neurons through an ERK/MAPK signaling-dependent mechanism. We speculate that this may be one mechanism by which environmental context facilitates some forms of drug experience-dependent plasticity, such as psychomotor sensitization.

Keywords: caudate nucleus, dopamine, immediate early genes, in situ hybridization, psychostimulants, rat.

J. Neurochem. (2004) 91, 337-348.
Psychostimulant drugs induce a complex pattern of gene expression in the striatum (Graybiel et al. 1990; Berke et al. 1998; see Harlan and Garcia 1998 for review), which represents an initial step in the induction of long-term changes in brain and behavior produced by drugs of abuse (Nestler et al. 1993; Chiasson et al. 1997; Sommer and Fuxe 1997; Hyman and Malenka 2001; Nestler 2001). However, the environmental context in which psychostimulant drugs are experienced modulates both their ability to induce forms of drug experience-dependent plasticity, such as psychomotor sensitization (Badiani et al. 1995a, 1995b; Crombag et al. 1996), and their ability to induce immediate early genes (IEGs) (Badiani et al. 1999; Uslaner et al. 2001b, 2003b). For example, when amphetamine is given in the home cage it induces IEGs almost exclusively in striatal neurons that co-express mRNA for dopamine D1 receptors, preprodynorphin and preprotachykinin, and form the striatonigral pathway (Berretta et al. 1992; Cenci et al. 1992; Johansson et al. 1994; Ruskin and Marshall 1994). When given in a novel test environment, however, amphetamine also induces IEGs in striatal neurons that co-express mRNA for dopamine D2 receptors and preproenkephalin, and form the striatopallidal pathway (Jaber et al. 1995; Badiani et al. 1999; Uslaner et al. 2001b, 2003b). Thus, the cells and circuits engaged by amphetamine vary according to where amphetamine is experienced, as does susceptibility to psychomotor sensitization.

The ability of amphetamine to engage IEGs in the striatum is dependent on both dopamine (Graybiel et al. 1990; Ruskin

Received April 4, 2004; revised manuscript received June 14, 2004; accepted June 16, 2004.

Address correspondence and reprint requests to Terry E. Robinson, Department of Psychology (Biopsychology), University of Michigan, 525 East University Avenue, Ann Arbor, MI 48109-1109, USA.

E-mail: ter@umich.edu

Abbreviations used: AMPA, $\alpha$-amino-3-hydroxy-5-methylisoxazole4-proprionate; DMSO, dimethyl sulfoxide; ERK, extracellular signalregulated kinase; IEG, immediate early gene; MAPK, mitogen-activated protein kinase; SSC, saline sodium citrate buffer. 
and Marshall 1994; LaHoste et al. 2000) and glutamate (Dragunow et al. 1991; Snyder-Keller 1991; Wang et al. 1994; Konradi et al. 1996), although amphetamine-evoked IEG expression in striatopallidal neurons is especially susceptible to glutamatergic regulation (Ferguson et al. 2003). Nonetheless, the striatopetal projections that regulate amphetamine-induced IEG expression in specific striatal cell populations have not been identified. A likely source is the neocortex, because it provides the major glutamatergic input into the striatum (Spencer 1976; Girault et al. 1986; McGeorge and Faull 1989), and the neocortex is strongly activated after amphetamine administration in a novel test environment, that is under conditions that also induce IEGs in striatopallidal neurons (Badiani et al. 1998). In addition, activation of the neocortex preferentially induces IEGs in striatopallidal neurons (Berretta et al. 1997, 1999; Parthasarathy and Graybiel 1997; Sgambato et al. 1997), an effect that occurs via the extracellular signal-regulated kinase $($ ERK)/mitogen-activated protein kinase (MAPK) signal transduction cascade (Sgambato et al. 1998; Gerfen et al. 2002).

The present experiments were designed to determine the source of striatopetal inputs that modulate the ability of amphetamine to engage striatofugal circuits. To do this we: (1) studied the effects of transection of corticostriatal fibers on amphetamine-evoked c-fos expression in striatofugal circuits; (2) characterized the effects of an ampakine, which preferentially enhances ongoing cortical activity, on amphetamine-evoked c-fos expression; and (3) determined the effect of a selective MEK inhibitor on amphetamine-evoked c-fos expression in striatofugal circuits.

\section{Materials and methods}

\section{Animals}

Male Sprague-Dawley rats (Harlan Sprague Dawley, Indianapolis, IN, USA) weighing 150-225 g upon arrival, were housed individually in clear square plastic cages containing shredded paper bedding, and were given a 1-week acclimatization period before any experimental manipulation. The rooms were temperature- and humidity-controlled, and maintained on a $14: 10 \mathrm{~h}$ light : dark cycle, with food and water available ad libitum. All experimental procedures were approved by the University of Michigan Committee on the Use and Care of Animals.

\footnotetext{
Drugs

D-Amphetamine sulfate (Sigma, St Louis, MO, USA) and the ampakine CX516 (generously donated by Cortex Pharmaceuticals, Irvine, CA, USA) were dissolved in sterile $0.9 \%$ saline. The MEK inhibitor SL327 (generously donated by Bristol-Myers-Squibb, Wilmington, DE, USA) was dissolved in $25 \%$ dimethylsulfoxide (DMSO) (diluted $1: 3$ in sterile water). All drugs were administered by i.p. injection in a volume of $1 \mathrm{~mL} / \mathrm{kg}$. Drug weights refer to the weight of the salts.
}

\section{Groups and test procedures}

Effect of transection of corticostriatal fibers on amphetamineevoked psychomotor activation and c-fos mRNA expression in identified striatal cell populations

Corticostriatal afferents originating from prefrontal and prelimbic cortices, and anterior portions of cingulate, primary sensorimotor and medial agranular cortices were transected using a modified version of the method described by Cenci and Bjorklund (1993). Rats were anesthetized with a mixture of ketamine hydrochloride $(100 \mathrm{mg} / \mathrm{mL}$ i.p.; Fort Dodge Animal Health, Fort Dodge, IA, USA), xylazine hydrochloride $(20 \mathrm{mg} / \mathrm{mL}$ i.p.; Ben Venue Laboratories, Bedford, $\mathrm{OH}, \mathrm{USA})$ and acepromazine maleate $(10 \mathrm{mg} / \mathrm{mL}$ i.p.; Vedco, St Joseph, MO, USA). Using standard stereotaxic procedures, a series of coronal cuts (4 mm wide total) were made either unilaterally or bilaterally with an inverted T-shaped knife that had a 2-mm wide blade (coordinates from bregma: anterior/posterior (A/P) $2.7 \mathrm{~mm}$; medial/lateral $(\mathrm{M} / \mathrm{L}) \pm 1.3 ; \pm 2.3 ; \pm 3.3 \mathrm{~mm}$; dorsal/ventral $(\mathrm{D} / \mathrm{V})$ -6.5 from the skull surface). Sham animals received a similar coronal cut, but the knife was only lowered $2 \mathrm{~mm}$ into the cortex (D/ $\mathrm{V}-3.0 \mathrm{~mm}$ from skull surface; i.e the white matter was not transected). A third group of animals had no surgery.

After a 1-week recovery period, rats were transported to a testing room where they received an injection of saline or amphetamine $(2 \mathrm{mg} / \mathrm{kg})$ and were placed into clear rectangular tubs $(217 \times 447 \times 230 \mathrm{~mm}$; i.e. a novel test cage $)$ containing a clear plastic insert in the center of the cage $(64 \times 230 \times 230 \mathrm{~mm})$ that formed a corridor through which rats could locomote, and ground corncob bedding on the floor. Behavior was recorded for $50 \mathrm{~min}$ and the total number of crossovers (defined by two consecutive beambreaks of sets of infrared photocells spaced $230 \mathrm{~mm}$ apart across the length of the tub) was used as an index of locomotor activity. Fifty minutes after injection, animals were decapitated. Brains were removed, frozen in isopentane and stored at $-70^{\circ} \mathrm{C}$.

Effect of an ampakine on amphetamine-induced psychomotor activation and c-fos $m R N A$ expression in identified striatal cell populations

Rats were transferred from the main animal colony room to a testing room and placed individually into cages identical to those described above for 1 week before testing. On the day of testing rats received an injection of saline or the ampakine CX516 (35 mg/kg) immediately followed by an injection of saline or amphetamine $(2 \mathrm{mg} / \mathrm{kg})$. Ampakines are positive modulators of $\alpha$-amino3-hydroxy-5-methylisoxazole-4-proprionate (AMPA) glutamate receptors, which slow the deactivation and desensitization of AMPA receptors, and so increase cortical activity by enhancing the amplitude and duration of fast, excitatory postsynaptic currents (Arai et al. 1996a, 1996b; Hess et al. 2003). CX516 has some preference for GluR2 receptors (A. Arai, personal communication), which are most abundant in the cortex and hippocampus (Martin et al. 1993; Beneyto and Meador-Woodruff 2004). Behavior was recorded for $50 \mathrm{~min}$ and then the animals were decapitated. Brains were removed, frozen in isopentane and stored at $-70^{\circ} \mathrm{C}$.

\section{Effect of a MEK inhibitor on amphetamine-evoked c-fos $m R N A$} expression in identified striatal cell populations

On the day of testing, rats received the highly selective MEK inhibitor SL327 $(10,20$ or $40 \mathrm{mg} / \mathrm{kg})$ dissolved in $25 \%$ DMSO 
(diluted $1: 3$ in sterile water), in the animal colony room. Thirty minutes later animals were transported to a testing room where they received an injection of saline or amphetamine $(2 \mathrm{mg} / \mathrm{kg})$, and then were placed individually into orange circular buckets with ground corncob bedding on the floor. Fifty minutes after the second injection animals were decapitated. Brains were removed, frozen in isopentane and stored at $-70^{\circ} \mathrm{C}$.

\section{Dual in situ hybridization}

Brains were sectioned using a cryostat and $16-\mu \mathrm{m}$ coronal sections were thaw-mounted on to Superfrost/Plus slides (Fisher Scientific, Pittsburgh, PA, USA) and stored at $-70^{\circ} \mathrm{C}$ until processing for dual in situ hybridization. The method was a modification of that described by Curran and Watson (1995). Slides containing four tissue sections were processed using a ${ }^{35}$ S-UTP and ${ }^{35}$ S-CTPlabeled riboprobe complementary to c-fos mRNA (680-mer; courtesy of Dr T. Curran, St Jude Children's Research Hospital, Memphis, TN, USA) and a digoxigenin-UTP-labeled riboprobe complementary to preproenkephalin mRNA (693-mer; courtesy of Dr J. Douglass, Amgen, Thousand Oaks, CA, USA). The radioactive riboprobe was generated by incubating linearized c-fos DNA $(1 \mu \mathrm{g})$ at $37^{\circ} \mathrm{C}$ for $1.5 \mathrm{~h}$ in $1 \times$ transcription buffer, $100 \mu \mathrm{Ci} \alpha{ }^{35} \mathrm{~S}-\mathrm{UTP}(100 \mathrm{Ci} / \mathrm{mm}, 20 \mathrm{mCi} / \mathrm{mL}$; Amersham, Arlington Heights, IL, USA), $160 \mu \mathrm{Ci} \alpha-{ }^{35} \mathrm{~S}-\mathrm{CTP}(800 \mathrm{Ci} / \mathrm{mM}, 40 \mathrm{mCi} /$ $\mathrm{mL}$; Amersham), $400 \mu \mathrm{M}$ GTP, $400 \mu \mathrm{M}$ ATP, $8 \mathrm{~mm}$ dithiothreitol, $10 \mathrm{U}$ Rnase inhibitor and $50 \mathrm{U}$ T7 RNA polymerase. The nonradioactive riboprobe was generated by incubating linearized preproenkephalin DNA $(1 \mu \mathrm{g})$ at $37^{\circ} \mathrm{C}$ for $1.5 \mathrm{~h}$ in $1 \times$ transcription buffer, $320 \mu \mathrm{M}$ digoxigenin-UTP (Boehringer, Manheim, Germany), $80 \mu \mathrm{M}$ UTP, $400 \mu \mathrm{M}$ GTP, $400 \mu \mathrm{M}$ ATP, $400 \mu \mathrm{M} \mathrm{CTP,} 10 \mathrm{~mm}$ dithiothreitol, $10 \mathrm{U}$ Rnase inhibitor and $50 \mathrm{U}$ T7 RNA polymerase. The resulting probes were incubated at room temperature $\left(22^{\circ} \mathrm{C}\right)$ with $83 \mathrm{U}$ Rnase-free Dnase for $15 \mathrm{~min}$ and then separated from free nucleotides on Micro Bio-Spin Chromatography columns (Bio-Rad, Hercules, CA, USA).

Before hybridization, tissue sections were fixed in $4 \%$ phosphatebuffered paraformaldehyde for $1 \mathrm{~h}$ at room temperature, rinsed three times in $2 \times$ saline sodium citrate buffer (SSC), placed into a solution of $0.1 \mathrm{M}$ triethanolamine $/ 0.25 \%$ acetic acid for $10 \mathrm{~min}$, rinsed in water and dehydrated in a series of graded alcohols (50-100\%). The ${ }^{35}$ S-labeled and digoxigenin-UTP-labeled probes were diluted in hybridization buffer $(50 \%$ formamide, $10 \%$ dextran sulfate, $3 \times \mathrm{SSC}$, $50 \mathrm{~mm}$ sodium phosphate, $\mathrm{pH} 7.4,1 \times$ Denhardt's solution and $10 \mathrm{mg} / \mathrm{mL}$ yeast tRNA) to give an approximate concentration of $3-4 \times 10^{6}$ d.p.m. per $80 \mu \mathrm{L}$ and $2.5 \mu \mathrm{L}$ per $80 \mu \mathrm{L}$ respectively. Slides were coverslipped with diluted probe $(80 \mu \mathrm{L})$ and placed in hybridization trays lined with filter paper dampened with $50 \%$ formamide $/ 50 \%$ water. The trays were sealed and incubated at $55^{\circ} \mathrm{C}$ for $16 \mathrm{~h}$. Coverslips were floated off in $2 \times$ SSC and the slides were rinsed three times in $2 \times$ SSC. The slides were then incubated in Rnase A $(200 \mu \mathrm{g} / \mathrm{mL})$ at $37^{\circ} \mathrm{C}$ for $1 \mathrm{~h}$, rinsed in $2 \times, 1 \times$ and $0.5 \times \mathrm{SSC}$, incubated in $0.1 \times \mathrm{SCC}$ at $65^{\circ} \mathrm{C}$ for $1 \mathrm{~h}$, and then cooled to room temperature. The slides were rinsed in $0.1 \mathrm{M}$ sodium phosphate buffer ( $\mathrm{pH} 7.4)$, incubated with shaking for $1 \mathrm{~h}$ at room temperature in a blocking solution $(0.25 \%$ carageenan, $0.5 \%$ Triton X-100, $0.1 \mathrm{~m}$ sodium phosphate buffer), and then incubated overnight with shaking at room temperature with an antibody against digoxigenin conjugated to alkaline phosphatase
(Fab fragments; Boehringer) that was diluted 1:10000 in a blocking solution. Slides were then incubated twice each for $1 \mathrm{~h}$ at room temperature with shaking in $0.1 \mathrm{~m}$ sodium phosphate buffer, twice each for $30 \mathrm{~min}$ in Tris-buffered saline and rinsed in alkaline substrate buffer (ASB; $100 \mathrm{~mm}$ Tris base, $50 \mathrm{~mm} \mathrm{NaCl}, 50 \mathrm{~mm}$ $\mathrm{MgCl}_{2}, \mathrm{pH}$ 9.5). The color reaction was carried out in the dark at room temperature in ASB containing 5\% polyvinyl alcohol, $0.025 \%$ levamisole and $2 \%$ nitro blue tetrazolium chloride/5-bromo-4chloro-3-indoyl phosphate (NBT/BCIP) (Boehringer). After approximately $4 \mathrm{~h}$ the color reaction was stopped by washing the slides extensively in water, incubating in $0.1 \mathrm{M}$ glycine containing $0.2 \%$ Triton $\mathrm{X}-100(\mathrm{pH} \mathrm{2.2)}$ for $10 \mathrm{~min}$ at room temperature and rinsing in water. Slides were then fixed in $2.5 \%$ glutaraldehyde for $2 \mathrm{~h}$, rinsed in water and air-dried.

Slides were exposed to X-ray film for 5 days (Kodak Biomax MR; Kodak, Rochester, NY, USA) and then dipped in emulsion (Ilford KD-5; Polysciences, Warrington, PA, USA) and stored in light-tight boxes at $4^{\circ} \mathrm{C}$ for 18 days. Slides were developed (Kodak $\mathrm{D}-19$ ) for $2.5 \mathrm{~min}$ at $17^{\circ} \mathrm{C}$, rinsed in water and fixed (Kodak Rapid Fix) for $5 \mathrm{~min}$ at $17^{\circ} \mathrm{C}$. They were then washed extensively in water, dehydrated in a series of graded alcohols (50-100\%), washed extensively in xylene and coverslipped with Permount mounting medium.

Control experiments using sense probes or tissue pretreated with Rnase A $\left(200 \mu \mathrm{g} / \mathrm{mL}\right.$ at $37^{\circ} \mathrm{C}$ for $\left.1 \mathrm{~h}\right)$ were performed to ensure probe specificity; no binding was observed with either control.

\section{Quantification of gene expression and data analysis}

Initial quantification of c-fos mRNA expression was conducted on autoradiographs across the rostrocaudal extent of the dorsomedial portion of the striatum (Paxinos and Watson 1998). This region was selected for analysis because it receives a dense glutamatergic projection from cortical regions, such as prefrontal, cingulate and parietal cortices (McGeorge and Faull 1989; Willuhn et al. 2003) and amphetamine-evoked c-fos expression is greatest in this region of the striatum (Badiani et al. 1998; Uslaner et al. 2001a). For some experiments, orbital, prefrontal, parietal and cingulate cortices were also quantified. Sections were quantified as described previously (Badiani et al. 1998).

For the cortical transection experiment, level $1.2 \mathrm{~mm}$ from bregma was selected for further analysis because transection of corticostriatal afferents produced the greatest decrease in amphetamine-evoked c-fos expression at this level. Level $-0.8 \mathrm{~mm}$ from bregma was also selected for further analysis because there was no effect of cortical transection at this level and so it was used as a positive control. In unilaterally transected/sham animals, only the transected/sham hemisphere was quantified. To allow for comparisons with the unilaterally transected animals, only one hemisphere was quantified in the bilaterally transected/sham animals and the animals that did not receive surgery; side was determined randomly.

For the ampakine experiment, the dorsomedial striatum at level $0.0 \mathrm{~mm}$ from bregma was selected for further analysis because this region receives a dense projection from parietal cortex (McGeorge and Faull 1989), and ampakines have been reported to preferentially enhance psychostimulant-evoked c-fos expression in parietal cortex (Hess et al. 2003). The ventromedial striatum at level $0.0 \mathrm{~mm}$ from bregma was also selected for further analysis; it was used as a positive control because there was no effect of ampakine pretreat- 
ment on amphetamine-evoked c-fos expression in orbital cortex, which sends a dense projection to this region (McGeorge and Faull 1989).

For the MEK inhibitor experiment, levels -0.4 and $-0.8 \mathrm{~mm}$ from bregma were selected for further analysis because amphetamine evokes the greatest amount of c-fos mRNA expression at more caudal levels (Badiani et al. 1998; Ostrander et al. 2003; Willuhn et al. 2003).

Quantification was carried out by an experimenter blinded to the experimental conditions. Sections from three to 10 animals per group were examined at $20 \times$ magnification using a microscope (Letiz DMR; Leica, Wetzler, Germany). For the cortical transection experiment, the number of single- and double-labeled cells in the dorsomedial striatum was counted in nine $250-\mu^{2}$ grids at level $1.2 \mathrm{~mm}$ from bregma and in four $250-\mu \mathrm{m}^{2}$ grids at level $-0.8 \mathrm{~mm}$ from bregma in one hemisphere (see Fig. 3). For the other experiments, the number of cells in two $250-\mu \mathrm{m}^{2}$ grids in each hemisphere was counted (a total of four grids per region or level). ${ }^{35} \mathrm{~S}$-labeled cells (containing c-fos mRNA; c-fos + ) appeared as silver grains under dark-field conditions and digoxigenin-labeled cells (containing preproenkephalin mRNA; Enk+) appeared as purple precipitate under bright-field conditions. Only ${ }^{35} \mathrm{~S}$-labeled cells that contained dense clusters of silver grains (at least 10 silver grains/ cell) and digoxigenin-labeled cells that were uniformly darkly stained (at least 10 times above background staining) were considered to be positively labeled. The number of preproenkephalin mRNA-positive cells did not differ between groups (data not shown). In all experiments, an untreated group that received no experimental manipulation was used to assess basal numbers of c-fos + cells, which was extremely low (i.e. fewer than five c-fos + cells $/ \mathrm{mm}^{2}$ ).

The vast majority of cells in the striatum are medium spiny projection neurons that either co-express mRNA for dopamine D2 receptors and preproenkephalin and form part of the striatopallidal pathway (Enk + or striatopallidal cells), or co-express mRNA for dopamine D1 receptors, preprodynorphin and preprotachykinin (but not preproenkephalin) and are part of the striatonigral pathway (Enk- or striatonigral cells). We have found that under our in situ conditions, preproenkephalin mRNA and preprotachykin mRNA co-localize in only $4 \%$ of cells in the striatum, confirming that Enk+ and Enk- cells represent two different and segregated cell populations (Gerfen 1992; Uslaner et al. 2003a). Amphetamine reportedly does not induce c-fos in interneurons in the striatum (Harlan and Garcia 1998) and, under our conditions, we have found that all amphetamine-evoked c-fos + cells are either co-labeled with preproenkephalin mRNA or preprodynorphin/preprotachykinin mRNA (Ferguson et al. 2003). Therefore, in the present study the number of c-fos + and Enk + cells (c-fos/ Enk+) was subtracted from the total number of c-fos + cells in the striatum for each animal to give the number of c-fos + and Enk(c-fos/Enk-) cells. This number was then used as an indication of the number of cells in the striatonigral pathway that were activated following each treatment.

\section{Statistical analysis}

For the cortical transection experiment, there were no group differences in locomotor activity, c-fos mRNA expression, number of c-fos/Enk+ cells or number of c-fos/Enk- cells in animals that received unilateral sham, bilateral sham or no surgery (as assessed by one-way ANOVA); these three groups were therefore pooled to form a single control group. In addition, there were no group differences in these measurements between animals that received unilateral or bilateral transections (assessed by means of a $t$-test), so these groups were pooled to form a single experimental group. For both the cortical transection and ampakine experiments, group differences in locomotor activity, c-fos mRNA expression, the number of c-fos/Enk+ cells and the number of c-fos/Enk- cells were tested using two-way ANOva followed by Bonferroni's post-hoc test. For the MEK inhibitor experiment, group differences in the number of c-fos/Enk+ cells and the number of c-fos/Enk- cells were examined using one-way ANOva followed by Dunnett's post-hoc test. For all comparisons, $\alpha=0.05$.

\section{Results}

\section{Transection of corticostriatal fibers selectively blocks amphetamine-evoked c-fos expression in striatopallidal (Enk+) neurons}

\section{Histology}

The extent of the cortical transection was examined in cresyl violet-stained coronal brain sections. A representative example of a unilateral transection is shown in Fig. 1. At levels corresponding to the knife cut, there was a clear absence of tissue. One transected animal was excluded from the study because no tissue damage was found, and two sham animals were excluded because tissue damage was observed in the corpus callosum.

\section{Locomotor behavior}

Animals given amphetamine made significantly more crossovers during the first $50 \mathrm{~min}$ after drug treatment than animals given saline (main effect of drug, $F_{1,48}=26.44$, $p<0.0001$ )(Fig. 2). However, there was no effect of cortical transection on saline- or amphetamine-induced locomotor activity (main effect of surgery and interaction between surgery and drug factors not significant, $F_{1,48}=0.01-3.28$, $p=0.08-0.94$ ) (Fig. 2).

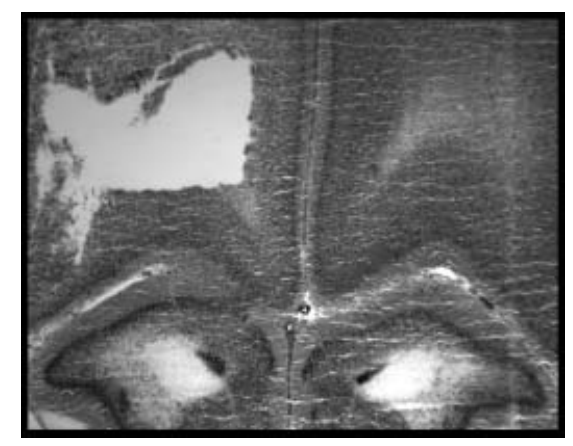

Fig. 1 Representative example of a cresyl violet-stained coronal brain section from a unilaterally transected animal. This level corresponds to the knife cut; there is a clear absence of tissue in and around the forceps minor of the corpus callosum. 


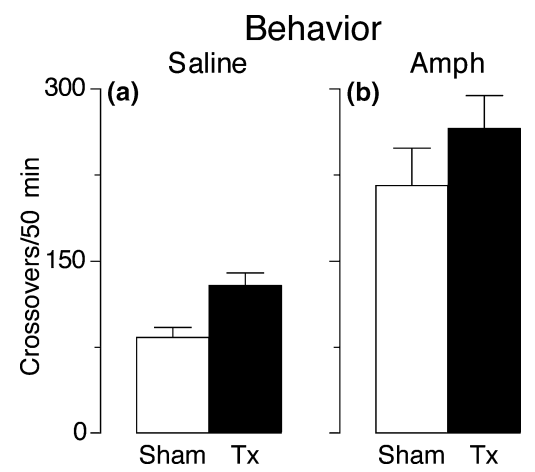

Fig. 2 Cortical transection does not alter the acute locomotor response to amphetamine (Amph). The mean \pm SEM number of crossovers made during the first $50 \mathrm{~min}$ after (a) saline treatment and (b) amphetamine treatment is shown in sham operated and transected (Tx) animals.

\section{$c$-fos $m R N A$}

Amphetamine evoked significantly more c-fos mRNA expression in the dorsomedial striatum than saline (main effect of drug at each level quantified, $F_{1,45-48}=9.86-$ 144.60, $p=0.0001-0.003$ ) (Fig. 3a). The effect of the corticostriatal transection on amphetamine-evoked c-fos expression in the dorsomedial striatum varied as a function of rostral-caudal position (Fig. 3a). At more rostral levels (1.6, 1.2 and $0.8 \mathrm{~mm}$ from bregma), two-way ANOvA revealed significant interactions between surgery and drug factors $\left(F_{1,45-47}=6.40-16.01, p=0.0002-0.01\right)$ (Fig. 3a). Posthoc tests showed that there were no differences between sham and transected animals given saline $(t=0.07-1.05$, $p>0.05$ ) (Fig. 3a), but there were significant differences between sham and transected animals given amphetamine $(t=2.7-5.92 ; p<0.001-0.05)$ (Fig. 3a), due to a decrease in amphetamine-evoked c-fos expression in transected animals. However, at more caudal levels $(0.4$ and $-0.8 \mathrm{~mm}$ from bregma), there were no effects of cortical transection on saline- or amphetamine-evoked c-fos expression (main effect of surgery and interaction between surgery and drug factors not significant at each level, $F_{1,46-48}=0.0001-2.62, p=0.11-0.99$ ) (Fig. 3a).

Figure 3 also shows the effect of transection on the number of amphetamine-evoked c-fos + cells in the striatum that were also Enk+ (striatopallidal cells) or Enk- (striatonigral cells) at levels $1.2 \mathrm{~mm}$ (Figs $3 \mathrm{~b}-\mathrm{e}$ ) and $-0.8 \mathrm{~mm}$ (Figs $3 \mathrm{f}-\mathrm{i}$ ) from bregma. Figure 3(j) shows representative examples of double-labeled c-fos/Enk+ cells. At both levels, amphetamine significantly increased the number of c-fos/ Enk + cells and the number of c-fos/Enk-cells compared with those in saline controls (main effect of drug at each level for each cell type, $F_{1,39-48}=6.82-108.50, p=0.001-0.0001$ ) (Figs 3b-i). At level $1.2 \mathrm{~mm}$ from bregma, there was a significant interaction in the number of c-fos/Enk+ cells between surgery and drug factors $\left(F_{1,48}=4.44\right.$, $p=0.04$ ) (Figs $3 \mathrm{~d}$ and e). Post-hoc tests revealed that there was no difference between sham and transected animals given saline $(t=0.80, p>0.05)$ (Fig. 3d), but there was a significant difference between sham and transected animals given amphetamine $(t=4.06, p<0.001)$ (Fig. 3e), due to a (mean \pm SEM) $56 \pm 7 \%$ decrease in the number of amphetamine-evoked c-fos/Enk+ cells in cortically transected animals. However, there was no effect of cortical transection on the number of saline- or amphetamine-evoked c-fos/Enkcells (main effect of surgery and interaction between surgery and drug factors not significant, $F_{1,48}=0.01-0.28$, $p=0.60-0.94$ ) (Figs $3 \mathrm{~b}$ and c). In contrast, at level $-0.8 \mathrm{~mm}$ from bregma, there was no effect of cortical transection on the number of saline- or amphetamine-evoked c-fos/Enk- cells or c-fos/Enk+ cells (main effect of surgery and interaction between surgery and drug factors not significant for each cell type, $F_{1,39}=0.01-0.46, p=0.50$ 0.93) (Figs 3f-i).

An ampakine selectively enhances amphetamine-evoked c-fos expression in striatopallidal $(\mathrm{Enk}+)$ neurons

\section{Locomotor behavior}

Animals given amphetamine made significantly more crossovers during the first $50 \mathrm{~min}$ following treatment than those given saline (main effect of drug, $F_{1,34}=39.72, p<0.0001$ ) (Fig. 4). However, ampakine pretreatment had no effect on saline- or amphetamine-induced locomotor activity (main effect of pretreatment and interaction between pretreatment and drug factors not significant, $F_{1,34}=0.03-0.55$, $p=0.46-0.86$ ) (Fig. 4).

\section{$c$-fos $m R N A$}

In all regions examined, there was no effect of ampakine pretreatment on a subsequent injection of saline. To simplify data presentation therefore, Fig. 5 shows data from amphetamine-treated groups only. The effect of ampakine pretreatment on amphetamine-evoked c-fos expression was examined in prefrontal (i.e. $\mathrm{Cg} 1$, prelimbic and infralimbic regions), orbital, cingulate and parietal cortices. Amphetamine evoked significantly more c-fos expression than saline in all cortical regions examined (main effect of drug for each region, $F_{1,34}=16.76-94.66, p<0.0001$; data not shown). In prefrontal, orbital and cingulate cortices, ampakine pretreatment had no effect on saline- or amphetamine-evoked c-fos expression main effect of pretreatment and interaction between pretreatment and drug factors not significant $\left(F_{1,34}=0.01-3.63, p=0.07-0.94\right)$ (Fig. 5d shows data for orbital cortex; data not shown for other regions). However, in parietal cortex there was a significant interaction in the amount of c-fos expression between pretreatment and drug factors $\left(F_{1,34}=10.09, p=0.003\right)$. Post-hoc tests revealed that there was no difference between saline- and 


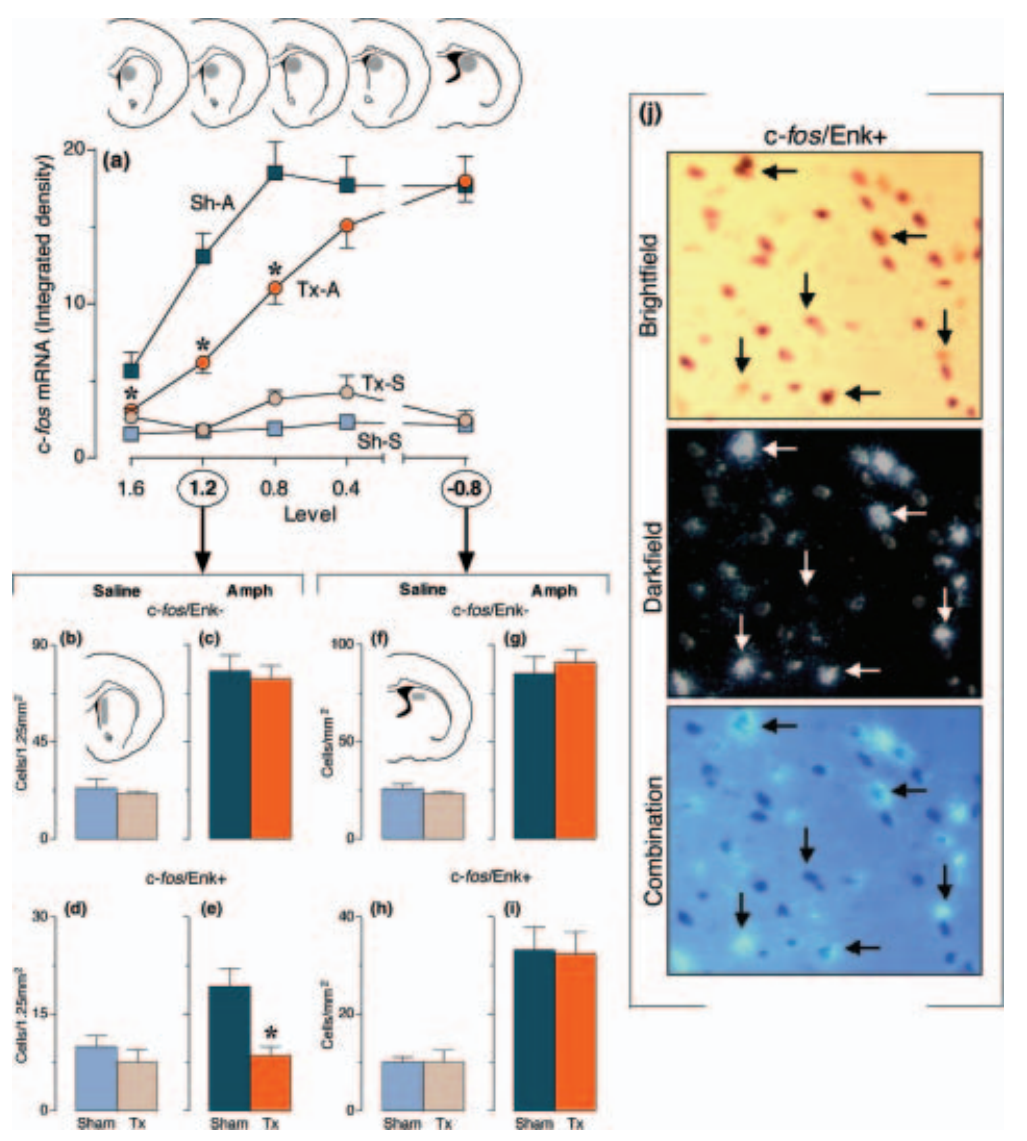

Fig. 3 Cortical transection selectively blocks the number of amphetamine-evoked c-fos/Enk+ cells in the dorsomedial striatum. (a) Mean \pm SEM c-fos expression (integrated density) across the rostral-caudal extent of the dorsomedial striatum. Sh-A, sham operated and amphetamine treated; Tx-A, transected and amphetamine treated; Sh-S, sham operated and saline treated; Tx-S, transected and saline treated. $(b, c)$ Mean \pm SEM number of $c-f o s / E n k-$ cells at level 1.2 after saline treatment (b) and amphetamine (Amph) treatment (c). Blue bars represent sham groups and orange bars represent transected (Tx) groups. (d, e) Mean \pm SEM number of c-fos/Enk+ cells at level 1.2 after saline treatment (d) and amphetamine treatment (e). (f, g) Mean \pm SEM number of c-fos/Enk- cells at level -0.8 after saline treatment (f) and amphetamine treatment $(\mathrm{g})$. ( $\mathrm{h}$, i) Mean \pm
SEM number of c-fos/Enk+ cells at level -0.8 after saline treatment (h) and amphetamine treatment (i). (j) Representative histological plates showing sections from the dorsomedial striatum that were doubledlabeled for c-fos mRNA and preproenkephalin mRNA. Sections were taken from an animal that received amphetamine treatment $(2 \mathrm{mg} / \mathrm{kg}$ i.p.) in a novel test environment. (Top) Brightfield image in which Enk+ cells are indicated by orange precipitate. (Middle) Darkfield image in which c-fos cells are indicated by clusters of silver grains. (Bottom) Overlay of brightfield and darkfield images. Downward facing arrows indicate single-labeled cells (c-fos+ or Enk+). Left facing arrows indicate double-labeled cells (c-fos/Enk+). ${ }^{*} p<0.05$ versus sham-operated amphetamine-treated group (two-way ANOVA with Bonferroni's post-hoc test). ampakine-pretreated animals given saline $(t=0.91$, $p>0.05$ ) (data not shown) but there was a significant difference between saline- and ampakine-pretreated animals given amphetamine $(t=3.66, p<0.01)$ (Fig. 5a), due to an increase in amphetamine-evoked c-fos expression in ampakine-pretreated animals. These results are consistent with a previous finding that ampakine pretreatment enhanced methamphetamine-induced c-fos expression in parietal but not frontal cortex (Hess et al. 2003), and suggest that the effect of the ampakine is region specific.

The effect of ampakine pretreatment on the number of amphetamine-evoked c-fos/Enk+ and c-fos/Enk- cells in the dorsomedial (Figs 5b and c) and the ventromedial (Figs 6e and $\mathrm{f}$ ) striatum at level 0.0 was also examined. In both regions, amphetamine significantly increased the number of c-fos/Enk+ cells and the number of c-fos/Enk- cells compared with saline (main effect of drug in each region for each cell type, $F_{1,34}=43.06-139.6, p<0.0001$ ) (data not shown). In the dorsomedial striatum, there was a significant interaction in the number of $\mathrm{c}-f o s /$ Enk + cells between pretreatment and drug factors $\left(F_{1,34}=9.72, p=\right.$ 0.004). Post-hoc tests showed that there was no difference between saline- and ampakine-pretreated animals given saline $(t=0.56, p>0.05)$ (data not shown), but there was 


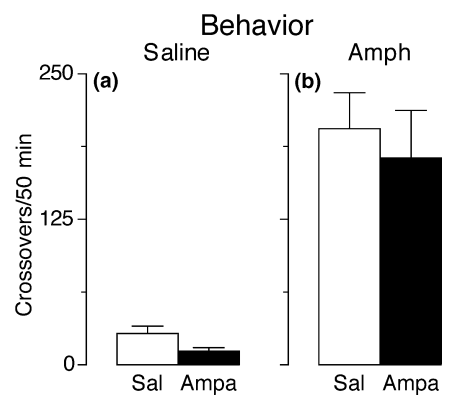

Fig. 4 Ampakine pretreatment does not alter the acute locomotor response to amphetamine. The mean \pm SEM number of crossovers made during the first 50 min after treatment with (a) saline and (b) amphetamine (Amph) in animals pretreated with saline (Sal) or ampakine (Ampa) is shown.

a significant difference between saline- and ampakinepretreated animals given amphetamine $(t=3.94, p<0.01)$ (Fig. 5c), due to a $120 \pm 37 \%$ increase in the number of amphetamine-evoked c-fos/Enk+ cells in ampakine-pretreated animals. However, there was no effect of ampakine pretreatment on the number of saline- or amphetamine-

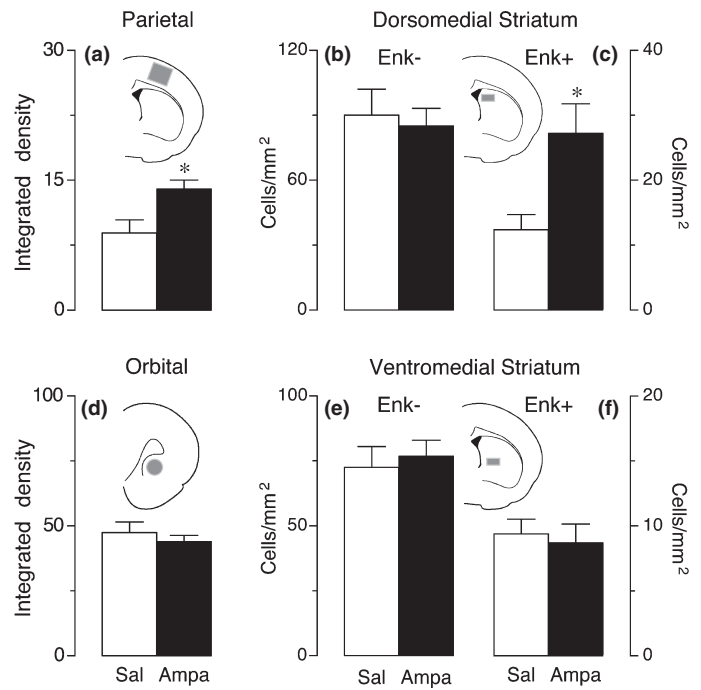

Fig. 5 Ampakine (Ampa) pretreatment selectively augments the number of amphetamine-evoked c-fos/Enk+ cells in the dorsomedial striatum. White bars represent the saline-pretreated group and black bars the ampakine-pretreated group. (a) Mean \pm SEM c-fos expression (integrated density) in parietal cortex at level 0.0 after amphetamine treatment. (b, c) Mean \pm SEM number of amphetamineevoked c-fos/Enk- cells (b) and c-fos/Enk+ cells (c) in dorsomedial striatum. (d) Mean \pm SEM c-fos expression (integrated density) in orbital cortex at level 2.6 after amphetamine treatment. (e, f) Mean \pm SEM number of amphetamine-evoked c-fos/Enk- cells (e) and $\mathrm{c}$-fos/Enk+ cells (f) in ventromedial striatum. ${ }^{*} p<0.05$ versus saline-pretreated amphetamine group (two-way ANOVA with Bonferroni's post-hoc test).

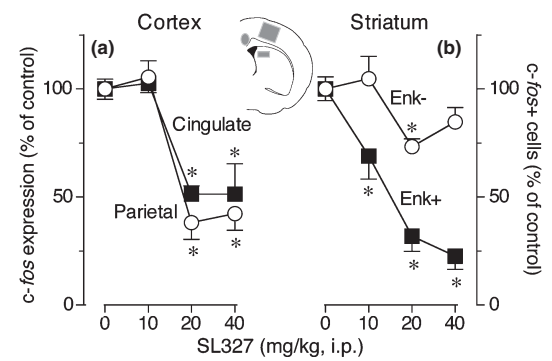

Fig. 6 Blockade of the ERK/MAPK signaling cascade preferentially attenuates the number of amphetamine-evoked c-fos/Enk+ cells in the dorsomedial striatum. Data represent an average of cell counts from levels -0.4 and -0.8 . (a) Mean \pm SEM percentage reduction in amphetamine-evoked c-fos expression in parietal $(\bigcirc)$ and cingulate (घ) cortices. (b) Mean \pm SEM percentage reduction in the number of amphetamine-evoked c-fos/Enk- cells $(\bigcirc)$ and c-fos/Enk+ cells ( $\mathbf{\square})$. ${ }^{*} p<0.05$ versus saline-pretreated amphetamine group (one-way ANOVA with Dunnett's post-hoc test).

evoked c-fos/Enk- cells (main effect of pretreatment and interaction between pretreatment and drug factors not significant, $F_{1,34}=0.03-0.68, p=0.42-0.86$ ) (Fig. 5b for amphetamine groups; data not shown for saline groups). Furthermore, in animals given amphetamine, there was a significant correlation between c-fos expression in the parietal cortex and the number of c-fos/Enk+ cells $(r=0.49, p=$ $0.03)$; the correlation with c-fos/Enk- cells was not significant. In contrast, in the ventromedial striatum, there was no effect of ampakine pretreatment on the number of saline- or amphetamine-evoked c-fos/Enk- or c-fos/Enk+ cells (main effect of pretreatment and interaction between pretreatment and drug factors not significant for each cell type, $F_{1,34}=0.002-1.14, p=0.29-0.97$ ) (Figs $5 \mathrm{e}$ and $\mathrm{f}$ for amphetamine groups; data not shown for saline groups).

\section{A MEK inhibitor attenuates amphetamine-evoked c-fos expression in the cortex and striatopallidal (Enk+) neurons in the striatum}

$c$-fos $m R N A$

The effects of SL327, a selective MEK inhibitor, on amphetamine-evoked c-fos expression in the cortex and striatum are shown in Fig. 6. Pretreatment with SL327 produced a significant dose-dependent decrease in amphetamine-evoked c-fos expression in parietal and cingulate cortices $\left(F_{3,19}=\right.$ 12.23-26.77, $p=0.0001$ ) (Fig. 6a). At the highest dose of SL327 tested, amphetamine-evoked c-fos expression in parietal cortex was decreased by $58 \pm 8 \%$ and amphetamineevoked c-fos expression in cingulate cortex was decreased by $53 \pm 10 \%$. Only pretreatment with $20 \mathrm{mg} / \mathrm{kg} \mathrm{SL} 327$ produced a significant decrease in the number of amphetamine-evoked c-fos/Enk- cells $\quad\left(F_{3,19}=5.35, \quad p=0.008\right) \quad$ (Fig. 6b). However, SL327 pretreatment produced a dose-dependent 
decrease in the number of amphetamine-evoked c-fos/Enk+ cells, which was statistically significant at all doses tested $\left(F_{3,19}=23.27, p<0.0001\right)$ (Fig. 6b). At the highest dose of SL327 tested, the number of amphetamine-evoked c-fos/Enkcells was decreased by $15 \pm 7 \%$, whereas the number of amphetamine-evoked c-fos/Enk+ cells was decreased by $77 \pm 6 \%$.

\section{Discussion}

Transection of corticostriatal projections reduced amphetamine-evoked c-fos expression in denervated regions of the striatum, consistent with previous reports (Cenci and Bjorklund 1993, 1994; Vargo and Marshall 1995, 1996). The present study extends these findings by demonstrating that the transection specifically altered the ability of amphetamine to engage striatopallidal (Enk + ) neurons, leaving the number of amphetamine-evoked c-fos + striatonigral (Enk-) neurons unchanged. If the ability of amphetamine to engage striatopallidal neurons is dependent on a corticostriatal input to the striatum, then activation of the cortex should facilitate amphetamine-evoked IEG expression selectively in striatopallidal neurons. Consistent with Hess et al. (2003), we found that administration of a positive modulator of AMPA glutamate receptors (i.e. an ampakine) selectively enhanced the ability of amphetamine to induce one marker of neuronal activity, c-fos, in the parietal cortex. In association with this increase in parietal activity, there was a two-fold increase in the number of cfos + striatopallidal neurons specifically in the striatal region that receives parietal input. There was, however, no effect on the number of c-fos + striatonigral neurons. Furthermore, in striatal regions innervated by cortical areas unaffected by the ampakine, there was no effect on the number of amphetamine-evoked c-fos + striatopallidal neurons. Collectively, these results suggest that corticostriatal (presumably glutamatergic) activity modulates the ability of amphetamine to engage striatopallidal, but not striatonigral, neurons.

Stimulation of corticostriatal inputs, as well as administration of glutamate or glutamate receptor agonists, can increase extracellular dopamine concentrations in the striatum (Nieoullon et al. 1978; Glowinski et al. 1988). It is possible therefore, that activation of corticostriatal glutamatergic afferents facilitates amphetamine-evoked IEG expression in striatopallidal neurons indirectly through a presynaptic mechanism, such as stimulation of dopamine release from the terminals of nigrostriatal dopaminergic neurons. Amphetamine is thought to induce IEG expression in striatonigral neurons primarily through dopamine-mediated mechanisms (Graybiel et al. 1990; Cole et al. 1994; Konradi et al. 1994), but we saw no effect of either corticostriatal transection or ampakine treatment on this cell population. These data therefore, suggest that glutamate does not modulate amphetamine-evoked IEG expression simply through alterations in striatal dopaminergic neurotransmission.

It is more likely that glutamate released from the cortex acts through a postsynaptic mechanism in the striatum to modulate amphetamine-evoked IEG expression in striatopallidal neurons. NMDA receptors in the striatum are mainly composed of NR1 subunits (which are necessary for formation of a functional receptor) in complex with either NR2A or NR2B subunits, which determine the pharmacological and physiological properties of the receptor (Buller et al. 1994; Laurie and Seeburg 1994; Standaert et al. 1994, 1999; Landwehrmeyer et al. 1995; Zukin and Bennett 1995). One promising target for the actions of glutamate is the NR2B-containing NMDA receptor located on medium spiny projection neurons. These receptors are regulated by corticostriatal afferents (Wullner et al. 1994; Kayadjanian et al. 1996), mediate a more sustained calcium influx than NR2A-containing NMDA receptors (Vicini et al. 1998) and are associated with enhanced behavioral and synaptic plasticity (Quinlan et al. 1999; Tang et al. 1999). In support of this hypothesis, we have shown that blockade of NR2B-containing NMDA receptors selectively attenuates the number of amphetamine-evoked c-fos + striatopallidal neurons, whereas blockade of both NR2B- and NR2A-containing NMDA receptors reduces the number of amphetamine-evoked c- $\mathrm{fos}^{+}$striatonigral and striatopallidal neurons (Ferguson et al. 2003). It should be noted, however, that dopamine modulates the ability of glutamate to engage striatopallidal neurons, as dopamine D1 and D2 receptor antagonists attenuate both amphetamine- and cortical stimulation-evoked IEG expression in these neurons (Liste et al. 1995; Ferguson et al. 2003).

It is widely accepted that psychostimulants induce IEGs through D1 receptor activation of the cyclic AMP/protein kinase A signaling cascade (Graybiel et al. 1990; Cole et al. 1994; Konradi et al. 1994). However, more recent work suggests that the ERK/MAPK signaling cascade is also an important pathway underlying psychostimulant-evoked IEG expression, because MEK inhibitors attenuate cocaine- and methamphetamine-evoked IEG expression in the striatum (Valjent et al. 2000; Salzmann et al. 2003). In addition, dopamine agonists evoke a greater c-fos response in the striatum of ERK1 knockout mice (which show enhanced stimulus-dependent phosphorylation of ERK2 protein) than in wild-type mice (Mazzucchelli et al. 2002). Importantly, the ERK/MAPK signaling cascade is activated primarily via increases in calcium, such as occurs following glutamatergic stimulation of NMDA receptors (Fiore et al. 1993; Xia et al. 1996; Sgambato et al. 1998; Vanhoutte et al. 1999; Gerfen et al. 2002). In the present study, we found that a MEK inhibitor produced only a small decrease in the number of amphetamine-evoked c-fos + striatonigral neurons, but nearly 
an $80 \%$ decrease in the number of $\mathrm{c}-f_{0}+$ striatopallidal neurons. The MEK inhibitor also produced a partial blockade (approximately 50-60\% decrease from control) of amphetamine-evoked IEG expression in relevant cortical regions. We cannot ascertain whether the number of c- $f \circ s^{+}$striatopallidal neurons was decreased through local actions of the MEK inhibitor within the striatum, or through actions at sites outside of the striatum (for example via decreases in corticostriatal afferent activity). Nonetheless, we can conclude that the ability of amphetamine to engage striatopallidal neurons is strongly dependent on activation of the ERK/ MAPK signaling cascade, whereas this signaling cascade has only a minor influence on the ability of amphetamine to activate striatonigral neurons.

Thus, we propose the following process for amphetamineevoked IEG expression in striatopallidal neurons. (1) Amphetamine administration in a novel test environment activates the neocortex. (2) This stimulates glutamate release in the striatum via corticostriatal afferents, which engages NR2B-containing NMDA receptors on striatopallidal medium spiny neurons. (3) In the presence of dopamine, these events initiate gene transcription through the ERK/MAPK signaling cascade. The nature of this dopamine-glutamate interaction is not yet understood. Furthermore, the functional significance of activation of striatopallidal neurons in mediating the actions of amphetamine is not yet known. However, conditions that promote cortical activation and engage striatopallidal neurons (amphetamine administration in a novel test environment) also promote amphetamineinduced behavioral sensitization (Badiani et al. 1995a, 1995b, 1998, 1999; Crombag et al. 1996; Uslaner et al. 2001b), and cortical lesions prevent the induction of locomotor sensitization to amphetamine (Wolf et al. 1995; Li and Wolf 1997; Cador et al. 1999).

Repeated psychostimulant treatment not only produces behavioral plasticity, but induces other forms of plasticity, such as NMDA receptor-dependent striatal long-term depression (Thomas et al. 2000; Thomas et al. 2001), and increased dendritic spine density in medium spiny striatal neurons (Robinson and Kolb 1997, 1999; Li et al. 2003). Importantly, glutamate and the ERK/MAPK signaling cascade have been implicated in these other forms of plasticity. For example, synaptic plasticity in the hippocampus is both NMDA receptor dependent (Brown et al. 1988) and ERK/ MAPK dependent (English and Sweatt 1996, 1997), and MEK inhibitors prevent one form of NMDA receptormediated structural plasticity, increased spine formation ( $\mathrm{Wu}$ et al. 2001; Goldin and Segal 2003).

In conclusion, we suggest that drug-environment interactions lead to recruitment of the ERK/MAPK signaling cascade in striatopallidal neurons via activation of glutamatergic corticostriatal afferents. This may promote behavioral sensitization, as well as the neurobiological adaptations associated with this form of drug experience-dependent plasticity.

\section{Acknowledgements}

This research was supported by a National Institute on Drug Abuse (NIDA) grant to TER (R37 DA04294). TER was supported by a NIDA Senior Research Scientist Award (K05 DA00473) and SMF by a NIDA Individual National Research Service Award (NRSA) (F31 DA14737). We thank Pengwei Yang and Yilin Li for their assistance in conducting these experiments.

\section{References}

Arai A., Kessler M., Ambros-Ingerson J., Quan A., Yigiter E., Rogers G. and Lynch G. (1996a) Effects of a centrally active benzoylpyrrolidine drug on AMPA receptor kinetics. Neuroscience 75, 573585.

Arai A., Kessler M., Rogers G. and Lynch G. (1996b) Effects of a memory-enhancing drug on DL-alpha-amino-3-hydroxy-5-methyl4-isoxazolepropionic acid receptor currents and synaptic transmission in hippocampus. J. Pharmacol. Exp. Ther. 278, 627-638.

Badiani A., Anagnostaras S. G. and Robinson T. E. (1995a) The development of sensitization to the psychomotor stimulant effects of amphetamine is enhanced in a novel environment. Psychopharmacology (Berl.) 117, 443-452.

Badiani A., Browman K. E. and Robinson T. E. (1995b) Influence of novel versus home environments on sensitization to the psychomotor stimulant effects of cocaine and amphetamine. Brain Res. 674, 291-298.

Badiani A., Oates M. M., Day H. E., Watson S. J., Akil H. and Robinson T. E. (1998) Amphetamine-induced behavior, dopamine release, and c-fos mRNA expression: modulation by environmental novelty. J. Neurosci. 18, 10579-10593.

Badiani A., Oates M. M., Day H. E., Watson S. J., Akil H. and Robinson T. E. (1999) Environmental modulation of amphetamine-induced c-fos expression in D1 versus D2 striatal neurons. Behav. Brain Res. 103, 203-209.

Beneyto M. and Meador-Woodruff J. H. (2004) Expression of transcripts encoding AMPA receptor subunits and associated postsynaptic proteins in the macaque brain. J. Comp. Neurol. 468, 530-554.

Berke J. D., Paletzki R. F., Aronson G. J., Hyman S. E. and Gerfen C. R. (1998) A complex program of striatal gene expression induced by dopaminergic stimulation. J. Neurosci. 18, 5301-5310.

Berretta S., Robertson H. A. and Graybiel A. M. (1992) Dopamine and glutamate agonists stimulate neuron-specific expression of Fos-like protein in the striatum. J. Neurophysiol. 68, 767-777.

Berretta S., Parthasarathy H. B. and Graybiel A. M. (1997) Local release of GABAergic inhibition in the motor cortex induces immediateearly gene expression in indirect pathway neurons of the striatum. J. Neurosci. 17, 4752-4763.

Berretta S., Sachs Z. and Graybiel A. M. (1999) Cortically driven Fos induction in the striatum is amplified by local dopamine D2-class receptor blockade. Eur J. Neurosci. 11, 4309-4319.

Brown T. H., Chapman P. F., Kairiss E. W. and Keenan C. L. (1988) Long-term synaptic potentiation. Science 242, 724-728.

Buller A. L., Larson H. C., Schneider B. E., Beaton J. A., Morrisett R. A. and Monaghan D. T. (1994) The molecular basis of NMDA receptor subtypes: native receptor diversity is predicted by subunit composition. J. Neurosci. 14, 5471-5484.

Cador M., Bjijou Y., Cailhol S. and Stinus L. (1999) D-Amphetamineinduced behavioral sensitization: implication of a glutamatergic 
medial prefrontal cortex-ventral tegmental area innervation. Neuroscience 94, 705-721.

Cenci M. A. and Bjorklund A. (1993) Transection of corticostriatal afferents reduces amphetamine- and apomorphine-induced striatal Fos expression and turning behaviour in unilaterally 6-hydroxydopamine-lesioned rats. Eur. J. Neurosci. 5, 1062-1070.

Cenci M. A. and Bjorklund A. (1994) Transection of corticostriatal afferents abolishes the hyperexpression of Fos and counteracts the development of rotational overcompensation induced by intrastriatal dopamine-rich grafts when challenged with amphetamine. Brain Res. 665, 167-174.

Cenci M. A., Kalen P., Mandel R. J., Wictorin K. and Bjorklund A. (1992) Dopaminergic transplants normalize amphetamine- and apomorphine-induced Fos expression in the 6-hydroxydopaminelesioned striatum. Neuroscience 46, 943-957.

Chiasson B. J., Hong M. G. and Robertson H. A. (1997) Putative roles for the inducible transcription factor c-fos in the central nervous system: studies with antisense oligonucleotides. Neurochem. Int. 31, 459-475.

Cole D. G., Kobierski L. A., Konradi C. and Hyman S. E. (1994) 6-Hydroxydopamine lesions of rat substantia nigra up-regulate dopamine-induced phosphorylation of the cAMP-response element-binding protein in striatal neurons. Proc. Natl Acad. Sci. USA 91, 9631-9635.

Crombag H. S., Badiani A. and Robinson T. E. (1996) Signalled versus unsignalled intravenous amphetamine: large differences in the acute psychomotor response and sensitization. Brain Res. $\mathbf{7 2 2}$, 227-231.

Curran E. J. and Watson S. J. Jr (1995) Dopamine receptor mRNA expression patterns by opioid peptide cells in the nucleus accumbens of the rat: a double in situ hybridization study. J. Comp. Neurol. 361, 57-76.

Dragunow M., Logan B. and Laverty R. (1991) 3,4-Methylenedioxymethamphetamine induces Fos-like proteins in rat basal ganglia: reversal with MK 801. Eur. J. Pharmacol. 206, 255-258.

English J. D. and Sweatt J. D. (1996) Activation of p42 mitogen-activated protein kinase in hippocampal long term potentiation. J. Biol. Chem. 271, 24329-24332.

English J. D. and Sweatt J. D. (1997) A requirement for the mitogenactivated protein kinase cascade in hippocampal long term potentiation. J. Biol. Chem. 272, 19103-19106.

Ferguson S. M., Norton C. S., Watson S. J., Akil H. and Robinson T. E. (2003) Amphetamine-evoked c-fos mRNA expression in the caudate-putamen: the effects of DA and NMDA receptor antagonists vary as a function of neuronal phenotype and environmental context. J. Neurochem. 86, 33-44.

Fiore R. S., Murphy T. H., Sanghera J. S., Pelech S. L. and Baraban J. M. (1993) Activation of p42 mitogen-activated protein kinase by glutamate receptor stimulation in rat primary cortical cultures. J. Neurochem. 61, 1626-1633.

Gerfen C. R. (1992) The neostriatal mosaic: multiple levels of compartmental organization. Trends Neurosci. 15, 133-139.

Gerfen C. R., Miyachi S., Paletzki R. and Brown P. (2002) D1 dopamine receptor supersensitivity in the dopamine-depleted striatum results from a switch in the regulation of ERK1/2/MAP kinase. J. Neurosci. 22, 5042-5054.

Girault J. A., Barbeito L., Spampinato U., Gozlan H., Glowinski J. and Besson M. J. (1986) In vivo release of endogenous amino acids from the rat striatum: further evidence for a role of glutamate and aspartate in corticostriatal neurotransmission. J. Neurochem. 47, 98-106.

Glowinski J., Cheramy A., Romo R. and Barbeito L. (1988) Presynaptic regulation of dopaminergic transmission in the striatum. Cell. Mol. Neurobiol. 8, 7-17.
Goldin M. and Segal M. (2003) Protein kinase C and ERK involvement in dendritic spine plasticity in cultured rodent hippocampal neurons. Eur. J. Neurosci. 17, 2529-2539.

Graybiel A. M., Moratalla R. and Robertson H. A. (1990) Amphetamine and cocaine induce drug-specific activation of the c-fos gene in striosome-matrix compartments and limbic subdivisions of the striatum. Proc. Natl Acad. Sci. USA 87, 6912-6916.

Harlan R. E. and Garcia M. M. (1998) Drugs of abuse and immediateearly genes in the forebrain. Mol. Neurobiol. 16, 221-267.

Hess U.S., Whalen S. P., Sandoval L. M., Lynch G. and Gall C. M. (2003) Ampakines reduce methamphetamine-driven rotation and activate neocortex in a regionally selective fashion. Neuroscience 121, 509-521.

Hyman S. E. and Malenka R. C. (2001) Addiction and the brain: the neurobiology of compulsion and its persistence. Nat. Rev. Neurosci. 2, 695-703.

Jaber M., Cador M., Dumartin B., Normand E., Stinus L. and Bloch B. (1995) Acute and chronic amphetamine treatments differently regulate neuropeptide messenger RNA levels and Fos immunoreactivity in rat striatal neurons. Neuroscience 65, 1041-1050.

Johansson B., Lindstrom K. and Fredholm B. B. (1994) Differences in the regional and cellular localization of c-fos messenger RNA induced by amphetamine, cocaine and caffeine in the rat. Neuroscience 59, 837-849.

Kayadjanian N., Heavens R. P., Besson M. J. and Sirinathsinghji D. J. (1996) Striatal NMDAR2B mRNA expression after bilateral cortical and unilateral nigral deafferentation. Neuroreport 7, 713-716.

Konradi C., Cole R. L., Heckers S. and Hyman S. E. (1994) Amphetamine regulates gene expression in rat striatum via transcription factor CREB. J. Neurosci. 14, 5623-5634.

Konradi C., Leveque J. C. and Hyman S. E. (1996) Amphetamine and dopamine-induced immediate early gene expression in striatal neurons depends on postsynaptic NMDA receptors and calcium. J. Neurosci. 16, 4231-4239.

LaHoste G. J., Henry B. L. and Marshall J. F. (2000) Dopamine D1 receptors synergize with $\mathrm{D} 2$, but not $\mathrm{D} 3$ or D4, receptors in the striatum without the involvement of action potentials. J. Neurosci. 20, 6666-6671.

Landwehrmeyer G. B., Standaert D. G., Testa C. M., Penney J. B. Jr and Young A. B. (1995) NMDA receptor subunit mRNA expression by projection neurons and interneurons in rat striatum. J. Neurosci. 15, $5297-5307$.

Laurie D. J. and Seeburg P. H. (1994) Ligand affinities at recombinant $N$-methyl-D-aspartate receptors depend on subunit composition. Eur. J. Pharmacol. 268, 335-345.

Li Y. and Wolf M. E. (1997) Ibotenic acid lesions of prefrontal cortex do not prevent expression of behavioral sensitization to amphetamine. Behav. Brain Res. 84, 285-289.

Li Y., Kolb B. and Robinson T. E. (2003) The location of persistent amphetamine-induced changes in the density of dendritic spines on medium spiny neurons in the nucleus accumbens and caudateputamen. Neuropsychopharmacology 28, 1082-1085.

Liste I., Rozas G., Guerra M. J. and Labandeira-Garcia J. L. (1995) Cortical stimulation induces Fos expression in striatal neurons via NMDA glutamate and dopamine receptors. Brain Res. 700, $1-12$.

Martin L. J., Blackstone C. D., Levey A. I., Huganir R. L. and Price D. L. (1993) AMPA glutamate receptor subunits are differentially distributed in rat brain. Neuroscience 53, 327-358.

Mazzucchelli C., Vantaggiato C., Ciamei A. et al. (2002) Knockout of ERK1 MAP kinase enhances synaptic plasticity in the striatum and facilitates striatal-mediated learning and memory. Neuron 34, 807-820. 
McGeorge A. J. and Faull R. L. (1989) The organization of the projection from the cerebral cortex to the striatum in the rat. Neuroscience 29, 503-537.

Nestler E. J. (2001) Molecular basis of long-term plasticity underlying addiction. Nat. Rev. Neurosci. 2, 119-128.

Nestler E. J., Hope B. T. and Widnell K. L. (1993) Drug addiction: a model for the molecular basis of neural plasticity. Neuron 11, 9951006.

Nieoullon A., Cheramy A. and Glowinski J. (1978) Release of dopamine evoked by electrical stimulation of the motor and visual areas of the cerebral cortex in both caudate nuclei and in the substantia nigra in the cat. Brain Res. 145, 69-83.

Ostrander M. M., Badiani A., Day H. E., Norton C. S., Watson S. J., Akil H. and Robinson T. E. (2003) Environmental context and drug history modulate amphetamine-induced c-fos mRNA expression in the basal ganglia, central extended amygdala, and associated limbic forebrain. Neuroscience 120, 551-571.

Parthasarathy H. B. and Graybiel A. M. (1997) Cortically driven immediate-early gene expression reflects modular influence of sensorimotor cortex on identified striatal neurons in the squirrel monkey. J. Neurosci. 17, 2477-2491.

Paxinos G. and Watson C. (1998) The Rat Brain in Stereotaxic Coordinates (4th edn). Academic, San Diego.

Quinlan E. M., Philpot B. D., Huganir R. L. and Bear M. F. (1999) Rapid, experience-dependent expression of synaptic NMDA receptors in visual cortex in vivo. Nat. Neurosci. 2, 352-357.

Robinson T. E. and Kolb B. (1997) Persistent structural modifications in nucleus accumbens and prefrontal cortex neurons produced by previous experience with amphetamine. J. Neurosci. 17, 8491-8497.

Robinson T. E. and Kolb B. (1999) Alterations in the morphology of dendrites and dendritic spines in the nucleus accumbens and prefrontal cortex following repeated treatment with amphetamine or cocaine. Eur. J. Neurosci. 11, 1598-1604.

Ruskin D. N. and Marshall J. F. (1994) Amphetamine- and cocaineinduced fos in the rat striatum depends on D2 dopamine receptor activation. Synapse 18, 233-240.

Salzmann J., Marie-Claire C., Le Guen S., Roques B. P. and Noble F. (2003) Importance of ERK activation in behavioral and biochemical effects induced by MDMA in mice. Br. J. Pharmacol. 140, 831-838.

Sgambato V., Abo V., Rogard M., Besson M. J. and Deniau J. M. (1997) Effect of electrical stimulation of the cerebral cortex on the expression of the Fos protein in the basal ganglia. Neuroscience $\mathbf{8 1}$, 93-112.

Sgambato V., Pages C., Rogard M., Besson M. J. and Caboche J. (1998) Extracellular signal-regulated kinase (ERK) controls immediate early gene induction on corticostriatal stimulation. J. Neurosci. 18, 8814-8825.

Snyder-Keller A. M. (1991) Striatal c-fos induction by drugs and stress in neonatally dopamine-depleted rats given nigral transplants: importance of NMDA activation and relevance to sensitization phenomena. Exp. Neurol. 113, 155-165.

Sommer W. and Fuxe K. (1997) On the role of c-fos expression in striatal transmission. The antisense oligonucleotide approach. Neurochem. Int. 31, 425-436.

Spencer H. J. (1976) Antagonism of cortical excitation of striatal neurons by glutamic acid diethyl ester: evidence for glutamic acid as an excitatory transmitter in the rat striatum. Brain Res. 102, 91-101.

Standaert D. G., Testa C. M., Young A. B. and Penney J. B. Jr (1994) Organization of $\mathrm{N}$-methyl-D-aspartate glutamate receptor gene expression in the basal ganglia of the rat. J. Comp. Neurol. 343, $1-16$.
Standaert D. G., Friberg I. K., Landwehrmeyer G. B., Young A. B. and Penney J. B. Jr (1999) Expression of NMDA glutamate receptor subunit mRNAs in neurochemically identified projection and interneurons in the striatum of the rat. Brain Res. Mol. Brain Res. 64, 11-23.

Tang Y. P., Shimizu E., Dube G. R., Rampon C., Kerchner G. A., Zhuo M., Liu G. and Tsien J. Z. (1999) Genetic enhancement of learning and memory in mice. Nature 401, 63-69.

Thomas M. J., Malenka R. C. and Bonci A. (2000) Modulation of longterm depression by dopamine in the mesolimbic system. J. Neurosci. 20, 5581-5586.

Thomas M. J., Beurrier C., Bonci A. and Malenka R. C. (2001) Longterm depression in the nucleus accumbens: a neural correlate of behavioral sensitization to cocaine. Nat. Neurosci. 4 , 1217-1223.

Uslaner J., Badiani A., Day H. E., Watson S. J., Akil H. and Robinson T. E. (2001a) Environmental context modulates the ability of cocaine and amphetamine to induce c-fos mRNA expression in the neocortex, caudate nucleus, and nucleus accumbens. Brain Res. 920 , $106-116$.

Uslaner J., Badiani A., Norton C. S., Day H. E., Watson S. J., Akil H. and Robinson T. E. (2001b) Amphetamine and cocaine induce different patterns of c-fos mRNA expression in the striatum and subthalamic nucleus depending on environmental context. Eur. J. Neurosci. 13, 1977-1983.

Uslaner J. M., Crombag H. S., Ferguson S. M. and Robinson T. E. (2003a) Cocaine-induced psychomotor activity is associated with its ability to induce c-fos mRNA expression in the subthalamic nucleus: effects of dose and repeated treatment. Eur. J. Neurosci. 17, 2180-2186.

Uslaner J. M., Norton C. S., Watson S. J., Akil H. and Robinson T. E. (2003b) Amphetamine-induced c-fos mRNA expression in the caudate-putamen and subthalamic nucleus: interactions between dose, environment, and neuronal phenotype. J. Neurochem. 85, 105-114.

Valjent E., Corvol J. C., Pages C., Besson M. J., Maldonado R. and Caboche J. (2000) Involvement of the extracellular signal-regulated kinase cascade for cocaine-rewarding properties. J. Neurosci. 20, 8701-8709.

Vanhoutte P., Barnier J. V., Guibert B., Pages C., Besson M. J., Hipskind R. A. and Caboche J. (1999) Glutamate induces phosphorylation of Elk-1 and CREB, along with c-fos activation, via an extracellular signal-regulated kinase-dependent pathway in brain slices. Mol. Cell. Biol. 19, 136-146.

Vargo J. M. and Marshall J. F. (1995) Time-dependent changes in dopamine agonist-induced striatal Fos immunoreactivity are related to sensory neglect and its recovery after unilateral prefrontal cortex injury. Synapse 20, 305-315.

Vargo J. M. and Marshall J. F. (1996) Frontal cortex ablation reversibly decreases striatal zif/268 and junB expression: temporal correspondence with sensory neglect and its spontaneous recovery. Synapse 22, 291-303.

Vicini S., Wang J. F., Li J. H., Zhu W. J., Wang Y. H., Luo J. H., Wolfe B. B. and Grayson D. R. (1998) Functional and pharmacological differences between recombinant $N$-methyl-D-aspartate receptors. J. Neurophysiol. 79, 555-566.

Wang J. Q., Daunais J. B. and McGinty J. F. (1994) NMDA receptors mediate amphetamine-induced upregulation of zif/268 and preprodynorphin mRNA expression in rat striatum. Synapse 18, 343-353.

Willuhn I., Sun W. and Steiner H. (2003) Topography of cocaineinduced gene regulation in the rat striatum: relationship to cortical inputs and role of behavioural context. Eur. J. Neurosci. 17, $1053-1066$. 
Wolf M. E., Dahlin S. L., Hu X. T., Xue C. J. and White K. (1995) Effects of lesions of prefrontal cortex, amygdala, or fornix on behavioral sensitization to amphetamine: comparison with $N$-methyl-D-aspartate antagonists. Neuroscience 69, 417-439.

Wu G. Y., Deisseroth K. and Tsien R. W. (2001) Spaced stimuli stabilize MAPK pathway activation and its effects on dendritic morphology. Nat. Neurosci. 4, 151-158.

Wullner U., Standaert D. G., Testa C. M., Landwehrmeyer G. B., Catania M. V., Penney J. B. Jr and Young A. B. (1994) Glutamate receptor expression in rat striatum: effect of deafferentation. Brain Res. 647, 209-219.

Xia Z., Dudek H., Miranti C. K. and Greenberg M. E. (1996) Calcium influx via the NMDA receptor induces immediate early gene transcription by a MAP kinase/ERK-dependent mechanism. J. Neurosci. 16, 5425-5436.

Zukin R. S. and Bennett M. V. (1995) Alternatively spliced isoforms of the NMDARI receptor subunit. Trends Neurosci. 18, 306-313. 